\title{
Comparative study between SnodgrassTubularised Incised Plate Urethroplasty versus Preputial Island Flap Repair in distal penile hypospadiasin respect to post operative fistula.
}

\author{
Dr. Tapas Kumar Majhi ${ }^{1}$, Dr. Ashis Kumar Saha ${ }^{2}$, Dr. Shib Shankar Kuiri ${ }^{2}$, \\ Dr. DevVrat Singh ${ }^{2}$, Dr. Chhanda Das ${ }^{3}$, Dr. Dipta Kanti Mukhopadhyay ${ }^{4}$ \\ ${ }^{1}$ (Department of Urology, B.S.Medical College, Bankura, India) \\ ${ }_{2}^{2}$ (Department of Surgery, B.S.Medical College, Bankura, India) \\ ${ }^{3}$ (Departmentof Pathology, IPGME\&R, Kolkata, India.) \\ ${ }_{4}^{4}$ (Department of Community Medicine, B.S.Medical College, Bankura, India)
}

\begin{abstract}
Hypospadias is a developmental halt of the genital tubercle which seems to be on the increase. Even though there is no universal technique for repair of hypospadias and each surgeon has his own convictions, sometime quiet wrong. There was a significant disparity of opinion between patients and surgeons about the cosmetic outcome. No direct comparison has been attempted between the Snodgrass repair and other established techniques and so we evaluated it with Preputial Island Flap repair in distal penile hypospadias in respect to post operative fistula. We took total of 40 patients of 3-8 years of age and divided 20 patients in each group. $45 \%$ cases of Snodgrass repair had a fistula while $20 \%$ of the patients underwent preputial island flap repair developed fistula.
\end{abstract}

Key Words: Hypospadias, Snodgrass repair, Preputial Island Flap

\section{Introduction}

Hypospadias is a developmental halt of the genital tubercle which seems to be on the increase according to various epidemiological studies ${ }^{[1]}$. The traditional goal of hypospadias surgery has been focused on the functional aspects of the repair, which are a straight penis with a glanular meatus to permit voiding while standing, and to allow effective coitus in adulthood ${ }^{[2]}$. In recent years several techniques have been proposed aiming to improve cosmesis, which is the principal aim of hypospadias surgery in distal hypospadias. Snodgrass initially proposed tabularized incised urethral plate urethroplasty as a surgical method of repairing distal hypospadias. This method has become popular as it claims to produce a vertically oriented, normal looking meatus which is cosmetically superior to other techniques ${ }^{[3,4]}$. The complication rate was acceptable and the technique was later recommended for proximal and re-operative hypospadias repair. Most reviews which measures the cosmetic outcome of hypospadias surgery has been based on assessing the views of the surgeons involved in managing the patients. The patients' view on the result of the older techniques has been analyzed recently. There was a significant disparity of opinion between patients and surgeons about the cosmetic outcome. In general, there is a lack of objective assessment of the cosmetic results of hypospadias repair by independent health professionals who have not been involved in the patients' care. No direct comparison has been attempted between the Snodgrass repair and other established techniques. Most classifications published are based on the position of urethral meatus which is insufficient criteria to determine the severity of hypospadias.

There is no universal technique for repair of hypospadias. Each surgeon has his own convictions, sometime quiet wrong. The multiplicity of techniques clearly demonstrates that none of them is fully satisfactory ${ }^{[5]}$. Main current debate splits the surgeons who are keen to solely use the ventral tissue to repair missing urethra and those who use dorsal tissue or other tissue claiming that ventral tissue alone cannot grow satisfactorilyThe ventral tissue used for repair of hypospadias was popularized by Snodgrass and dorsal tissue popularized by Asopa ${ }^{[6]}$.

\section{Aims And Objectives}

Our aim of the study is to compare the result of hypospadias repair using Snodgrass technique versus preputial island flap repair in distal penile hypospadias in context to development of fistula which is the most common complication after hypospadias repair.

\section{Materials And Methods}

The prospective clinical study was performed in the Department of Urology of Bankura Sammilani Medical College, Bankura, West Bengal, India in 2012 (January to December). 
Hypospadias was diagnosed by physical examination which was suspected by ventrally deficient prepuce and confirmed by proximal meatus. Most of the patients were of age 3 years to 8 years of age. Patients with severe chordee which discouraged $1^{\text {st }}$ stage repair were excluded from the study.Patients with wide urethral plate were selected for Snodgrass repair and others were selected for preputial island flap repair.

Factors considered before deciding on the most appropriate technique of reconstruction are:1] Level of division of corpus spongiosum, 2] Degree of hypoplasia of the tissue forming the ventral aspect of penis, 3] Quality of urethral plate, 4] Size of penis, 5] Size of glans, 6] Availability of preputial skin, 7]Ano-scrotal distance or ano-penile distance which may reflect the degree of prenatal androgen exposure

All boys received temporary urinary diversion with an 8 Fr Nelatons catheter, which remained in place for 7 to 14 days. Patients were seen at the time of stent or catheter removal (1 to 2 weeks postoperatively), and then monthly follow up for 3 months. Complications were documented after the first repair. The site and size of fistula if any was recorded and documented which is the principal aim of our study.

\section{Results And Analysis}

Out of 20 patients who underwent Snodgrass repair 9(45\%) had a fistula on the $10^{\text {th }}$ postoperative day. 2 cases developed proximal fistula and the rest had distal fistula. While for the other 20 patients who underwent preputial island flap repair, 4(20\%) developed fistula. The complications are tabulated below

Table1: Showing complications in each group of patients

\begin{tabular}{|c|c|c|}
\hline & $\begin{array}{c}\text { Snodgrass repair } \\
\mathrm{n}=20\end{array}$ & $\begin{array}{c}\text { Preputial island flap repair } \\
\mathrm{n}=20\end{array}$ \\
\hline Fistula / breakdown & 12 & 5 \\
\hline Fistula proper & 9 & 4 \\
\hline Breakdown & 3 & 1 \\
\hline Location of fistula & 7(proximal)+2(distal) & 2(proximal)+ 1(distal) \\
\hline
\end{tabular}

\section{Discussion}

Our experience suggests that the TIP and Preputial island flap procedures are clinically equivalent for repairing distal hypospadias, since they have similar overall complication rates. Although this was a single institution consecutive patient series, a selection bias likely to exist by virtue of retrospective limitations. On the other hand, since the prospective patient characteristics were similar in each group, this series shows an equal application of each technique to the same type of hypospadias defect. Furthermore, Snodgrass and preputial island flap cases were age matched, had similar types of defect and had equal rates of distal penile transposition, reflecting similarities between the groups and allowing for potentially meaningful comparison.

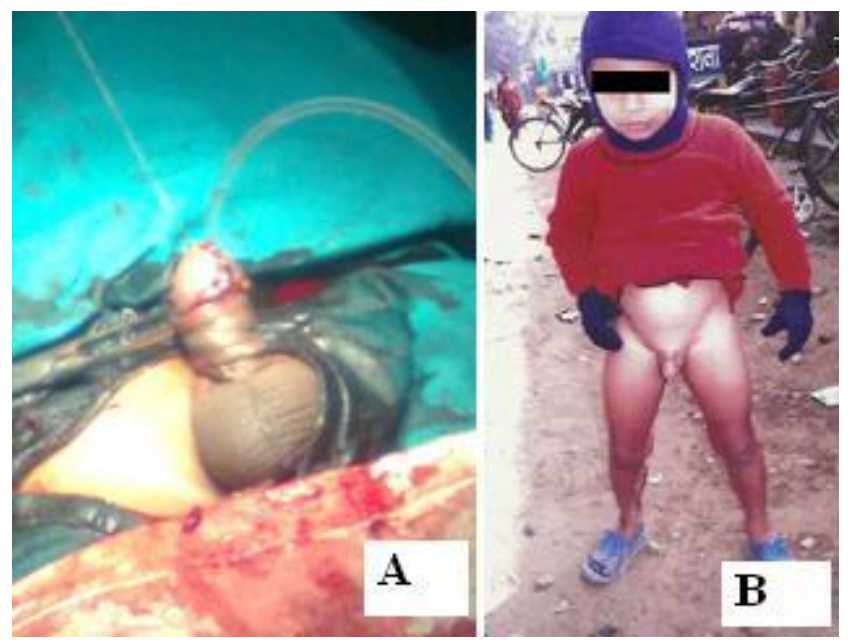

Figure 1: [A] Per operative picture of preputial island flap repair, [B] showing mid stream urine flow after preputial island flap repair

Although the overall complication rate was similar for both techniques, some differences became evident when the type of complication was analyzed. Fistula rate was significantly higher after Snodgrass as compared to preputial island flap repair. Furthermore, fistula location was strictly different between the two techniques, with fistula occurring in $45 \%$ of patients following Snodgrass and in $20 \%$ following Preputial island flap repair. This particular finding is intriguing. Rate of proximal fistula in Snodgrass and preputial island flap repair being $35 \%$ and $10 \%$ respectively. Despite performing urethroplasty over an 8 Fr catheter in both techniques, the preponderance of proximal fistula suggests that an increased flow resistance in Snodgrass repair. 
In our study we have seenthat 9 out of 20 patients who underwent Snodgrass method developed fistula of which 7 had proximal fistula. While patients who underwent preputial island flap repair 4 out of 20 developed fistula of which 2 had proximal fistula. Thus we see that Snodgrass repair has a higher incidence of fistula compared to preputial island flap repair.

\section{Conclusion}

Thus we see that Snodgrass tubularised incised plate urethroplasty has a higher incidence of fistula as compared to preputial island flap repair.

\section{References:}

[1] Duckett JW, Hypospadias. In Walsh PC, Ritik A, Vaughan ED Jr, Wein AJ eds, Campbell's Urology, $7^{\text {thedn, Chapt }}$ 68.Philadelphia: WB Saunders, 1998: 2097-98

[2] Moriya K, Kakizaki H, Tanaka H, Furuno T, Higashiyama H, Sano H, Kitta T, Nonomura K.Long-term cosmetic and sexual outcome of hypospadias surgery: norm related study in adolescence.J Urol. 2006 Oct; 176:1889-93

[3] Snodgrass WT, Lorenzo A. Tubularised incised plate urethroplasty for proximal hupospadias, BJU Int 2002;89:90-3

[4] Snodgrass W, Koyle M, Manzoni G, Hurwitz R, Caldamone A, Ehrlich R: Tubularized incised plate hypospadias repair for proximal hypospadias. J Urol, 159: 2129, 1998

[5] Baskin L, Erol A, Li YW, Cunha G: Anatomical Studies of Hypospadias. J Urol, 160: 1108-15

[6] Asopa HS, Garg M, Singhal GG, Singh L, Asopa J, Nischal A. Dorsal free graft urethroplasty for urethral stricture by ventral sagittalurethrotomy approach. Urology 2001;58:657-9. 